DOI: $10.1515 /$ plass-2017-0024

Danuta Strzelczyk-Żyta

Plant Breeding and Acclimatization Institute - National Research Institute, Młochów Research Center, Platanowa Str. 19, 05-831 Młochów, Poland; e-mail: d.zyta@ihar.edu.pl

\title{
IN VITRO PRESERVATION OF POTATO PLANTS
}

\begin{abstract}
Potato plants free of viruses, bacteria and viroid could be maintained in vitro for a long time. Proper preparation of potato plants for in vitro culture provide its long-term storage in good condition. First step is to establish in vitro culture from young greenhouse grown plants in early developmental stage. Explants are maintained and propagated by nodal subculture on hormone-free Murashige and Skoog (MS) medium at temperature $20-22^{\circ} \mathrm{C}$. After rooting, for longer preservation plants are maintained at temperature $8-10^{\circ} \mathrm{C}$.
\end{abstract}

Key words: long-term storage, potato collections, in vitro culture of potato

\section{INTRODUCTION}

Preservation of the biodiversity of wild and cultivated plant species, including the potato crop Solanum tuberosum L. and its relatives, is an important task for the collection of plant genetic resources. There are many collections in the world that maintain a large and varied gene pool of Solanum. Various methods of storing potato genotypes, such as field or greenhouse propagation, seeds, in vitro plants, are used in plant collections. Vegetatively propagated potato is often maintained in field collections. It is a traditional method, requiring a lot of space and work. In addition, field collections are not available throughout the year, and preserved material is exposed to biotic and abiotic stresses during the growing season and during storage, which may lead to its loss. Potato produces true seeds that can be stored for a long time, but the plants obtained from the true seeds sample are not homogeneous, and cannot preserve valuable single genotypes (Engelmann, 2011). Commonly used method to protect potato genotypes in gene banks is in vitro cultures. The in

Communicated by Ewa Zimnoch-Guzowska 
vitro culture method ensures the production and rapid multiplication of disease-free material. In this technique the effects of unfavorable environmental factors are eliminated because genotypes are stored under controlled conditions. Maintenance of in vitro plants in low temperature reducing growth of plant material and increasing intervals between subcultures (Engelmann, 2011). However, somaclonal variation within the genotype may occur in the long-term stored in vitro (Belokurova, 2010; Engelmann, 2011). In Bonin Research Center of IHAR-PIB the method of micropropagation of in vitro potato plants was developed in 1980 (Zaklukiewicz et al., 1995; Sekrecka and Michałowska, 2015). In IHAR-PIB Młochów Research Center this method has been used since 1986 for in vitro collection of diploid and tetraploid research materials including parental lines.

\section{MATERIALS AND REAGENTS}

1) Murashige and Skoog Medium Including Vitamins (Duchefa Biocheme, cat. No P11872.02)

2) Plant Agar (Duchefa Biochemie cat. No BO 11493)

3) Sucrose Pure P.A. (POCH cat. No 772090110)

4) Lysogeny Broth (LB, Luria Bertani) (Sigma Aldrich, cat No L3152)

5) Ethanol (CHEMIPU, cat. No113964200)

6) Combitips advanced, (Eppendorf BIOPUR, cat. No 0030089693)

7) Distilled water

8) Glass test tubes (Roth, cat. No TX22.1)

\section{SOLUTIONS}

1) MS medium with $3 \%$ sucrose and $0.8 \%$ agar

2) LB medium with $10 \mathrm{~g} \times 1^{-1}$ Tryptone, $5 \mathrm{~g} \times 1^{-1}$ Yeast, Extract $5 \mathrm{~g} \times \mathrm{1}^{-1}$ $\mathrm{NaCl}$ (Sigma Aldrich cat. No L3022), autoclaved for 15 minutes at $121^{\circ} \mathrm{C}$ to sterilize

\section{EQUIPMENT}

1) Laminar flow cabinet (POLON, cat. No KL-21)

2) Multi-pipette (Eppendorf, cat. No 4981000 019)

3) $\mathrm{Ph}$ meter (Mera, cat. No HI2020-02)

4) Autoclave (HP Medizntechnik, Varioklav, cat. No 50085006)

5) Plant growth chamber $\left(22^{\circ} \mathrm{C}\right.$, light intensity $\left.8000 \mathrm{Lux}\right)$

6) Plant growth chamber for long storage $\left(8-10^{\circ} \mathrm{C}\right.$, light intensity 1000 Lux)

\section{PROCEDURE}

In order to established in vitro plants of selected genotypes presence of common viruses of potato (PVY, PVX, PVM, PVS and PLRV), Clavibacter michi- 
ganesis, Ralstonia solanacearum and potato spindle tuber viroid (PSTVd) infections are checked in plants grown in greenhouse conditions. Forms free of pathogens are established in vitro by cutting plant fragments with apical or auxiliary buds and decontaminated with sterilizing agents.

1) It is taken 10 fragments with apical or auxiliary buds from about 3 greenhouse grown plants from one genotype. The size of explants is about $1 \mathrm{~cm}$ (Photo 1). Generally, younger plants, with more rapidly growing tissues in early developmental stage are the most effective for in vitro propagation.

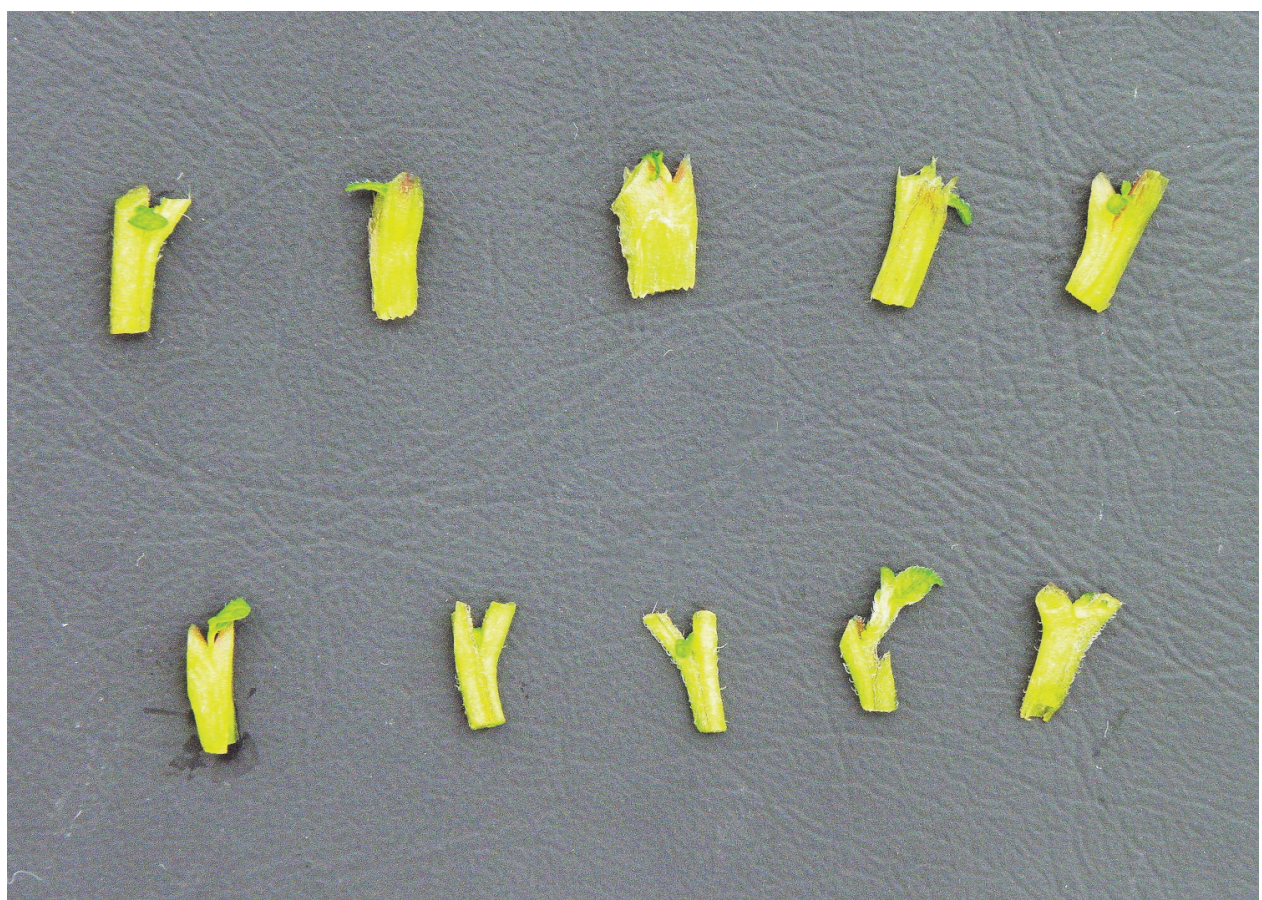

Photo. 1. The potato explants after sterilization.

2) Plant explants are immersed in the $70 \%$ ethanol for $20-30 \mathrm{~s}$.

3) Explants are placed in $2 \%$ solution of sodium hypochlorite diluted in water in ratio 1:5 for 4-7 min.

4) Explants are washed with sterile distilled water three times for five minutes each time. Steps 1-4 are done with sterile tools and in sterile conditions.

5) A successful sterilization is achieved when the explants are decontaminated and remains viable.

6) Following the sterilization step, explants are maintained and propagated by nodal subculture on hormone-free MS medium (Murashige and Skoog, 1962) with 3\% sucrose and $0.8 \%$ agar. Ten in vitro plants per genotype are maintained in the collection (Photo 2). 


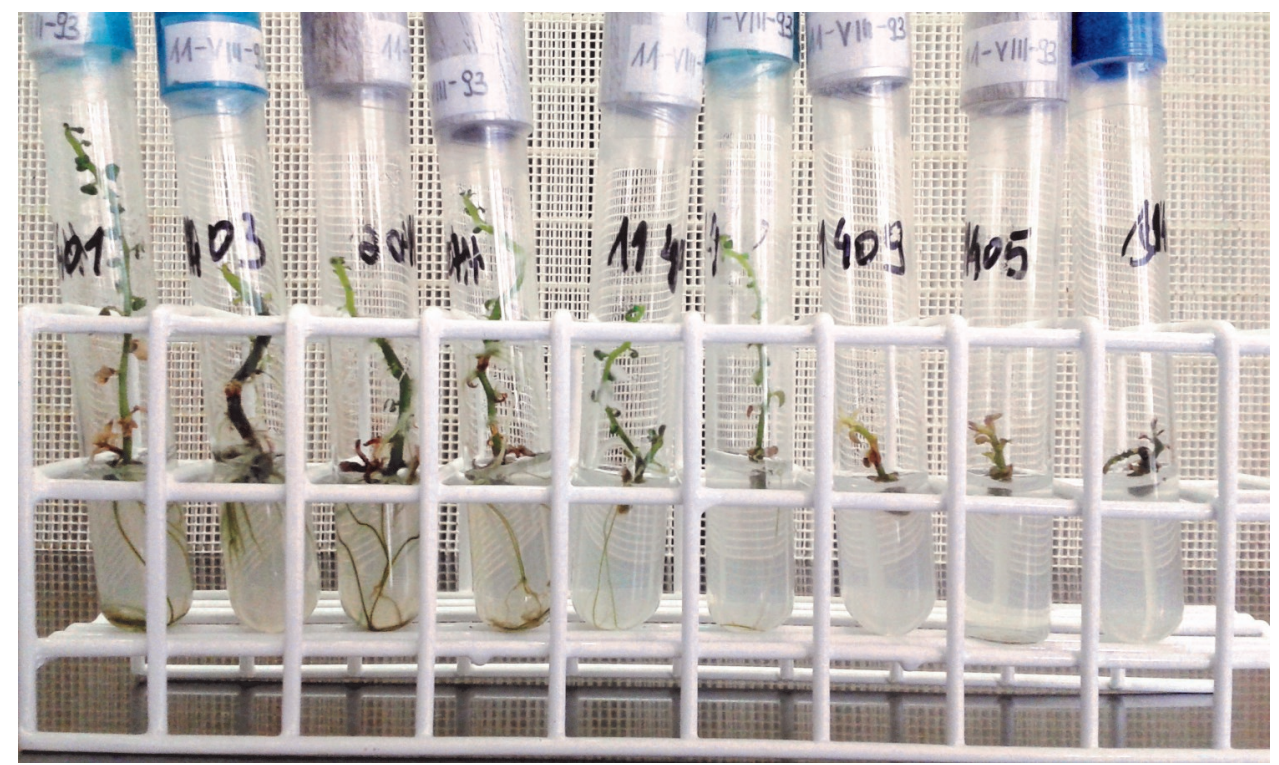

Photo 2. Plantlets maintained in the in vitro collection

7) Plants are kept in chambers at a temperature of $20-22^{\circ} \mathrm{C}$ and illuminated 5-8 thousand lux to obtain well-developed and rooted plants in a tube (for about 1 month). Plants in good condition (at least 3 plants) considered as healthy are the starting material for further reproduction in micropropagation.

8) The presence or absence of non-pathogenic bacteria is checked on LB (lysogeny broth; Luria - Bertani) medium. Parts of the in vitro plantlets are placed in liquid LB media. Opacification of LB medium after 7 days of incubation at room temperature indicates the presence of bacteria in plant material.

9) In order to reduce the aging of the stored material, the rooted plants on MS medium at a temperature of $20-22^{\circ} \mathrm{C}$ are transferred to chambers at a temperature of $8-10^{\circ} \mathrm{C}$ and illumination of about 1000 lux.

\section{ACKNOWLEDGEMENTS}

This work was financed by the Polish Ministry of Agriculture and Rural Development, Multiannual program "Creating the scientific basis for biological progress and the protection of plant genetic resources as source of innovation and support for sustainable agriculture and food security of the country" Task 1.2. Collecting, maintaining in field and in vitro collections, cryopreservation, characteristics, evaluation, documentation and sharing of genetic resources of diploid potato. 


\section{REFERENCES}

Belokurova V.B. 2010. Methods of Biotechnology in System of Efforts Aimed at Plant Biodiversity Preservation (Review). Cytol. Genet. 44:174-185.

Engelmann F. 2011. Use of biotechnologies for the conservation of plant biodiversity. In vitro Cell. Dev.-Pl 47: 5-16

Sekrecka D., Michałowska D. 2015. Mikrorozmnażanie - technologia wykorzystywana w produkcji zdrowych sadzeniaków ziemniaka. Ziemniak Polski 3: 3-7 (in Polish).

Zaklukiewicz K., Turska E., Sekrecka D. 1995. Technologia Mikrorozmnażania Roślin ziemniaka, Produkcja Minibulw oraz ich Wykorzystanie w Hodowli i Nasiennictwie. Instrukcja wdrożeniowa $\mathrm{Nr} 2 / 95$ (in Polish). 